overall efficiency. A domestic electrification policy is outlined with special reference to space- and waterheating for working-class houses, and it is suggested that future policy in the domestic electrification of houses should be based on the use of a proportion of solid fuel for heating and water-heating.

\section{Bee-keeping in War-time}

AT a lunch of the Backs to the Land Club held on March 25, Dr. C. G. Butler, of the Rothamsted Experimental Station, gave an address on the place of bee-keeping in the national economy. As Dr. Butler pointed out, it appears to be the common idea that the value of the honey-bee lies in the honey it produces. From the point of view of national economy, however, its function as the pollinator for fruit and seed crops is of prime importance. Honey has not been found to contain any measurable quantity of vitamins, but its invert sugars make it very readily assimilated by the human body. It is therefore of special value in treating cases of shock; also invalids and young children. Dr. Butler stressed the undesirability of too many beginners taking up bee-keeping at the present time. The shortage of supplies, in his opinion, is such that established bee-keepers should have first claim on such supplies, rather than the novice knowing nothing at all about bees. There is evidence that in many places where large orchards, or areas of insect-pollinated seed crops are planted, there are insufficient wild pollinating insects present for full production. Dr. Butler urges that, at the present time, greater efforts should be made to use honey-bees for pollination by making them available by the transfer of stocks to such areas where they are most needed.

\section{Wilhelm August Lampadius (1772-1842)}

Ax the time when geologists and mining students flocked to the Freiberg Mining Academy in Saxony, and when Gottlob Werner was at the height of his fame, a twenty-year-old chemist because a member of the staff, and from that time onwards for half a century he taught, wrote and experimented with great success. This young chemist was Wilhelm August Lampadius, who in his fourteenth year had been apprenticed to a Göttingen apothecary. Born at Hehlen in Brunswick on August 8, 1772, Lampadius lost his father, a pastor, at an early age. Apprenticed by his mother at Göttingen he devoted his spare time to study and was befriended by the university professors J. F. Gmelin and Lichtenburg. At the age of nineteen he entered the service of the metallurgist Count Sternberg of Bohemia. With the Count he made a journey to Russia and in the Count's laboratory made experiments on electricity and heat. His talents becoming known to Werner, he was given a post at Freiberg and on the death of C. E. Gellert (1713-1795) he was made professor of chemistry. In this situation he assisted German industry in many ways. He spread a knowledge of Lavoisier's discoveries, and made researches connected with mining and metallurgy, chemical manufactures, agriculture and meteorology. Especially important among the books he published was his handbook on smelting. A man of estimable character, respected alike by his friends and colleagues, he died at Freiberg on April 13,1842 ) in his seventieth year. Fis place in the Academy was taken by Karl Friedrich Plattner (1800-1858), the chief of the royal department of assaying and an authority on the use of the blow pipe.

\section{Earthquakes Registered at Kew}

DURING February 2-March 5 four large earthquakes were registered on the seismographs at Kew Observatory. The first, on February 2; began recording at $17 \mathrm{~h} .15 \mathrm{~m}$. 28s. U.T., possibly from an epicentral distance of $1,500 \mathrm{~km}$., though long waves were not pronounced and the shock appeared to possess some of the deep-focus characteristics. On February 16 a strong shock began recording at $18 \mathrm{~h}$. $27 \mathrm{~m}$. 3ls. U.T., possibly from an epicentral distance of $13,300 \mathrm{~km}$. It finished recording at $20 \mathrm{~h} .00 \mathrm{~m}$., having lasted some $1 \mathrm{~h} .32 \cdot 5 \mathrm{~m}$. The third earthquake, on February 21, began recording on all three components with $i P$ compressional at $07 \mathrm{~h} .20 \mathrm{~m}$. 14s. The tentative calculated epicentral distance was $9,300 \mathrm{~km}$. The shock appeared to be normal, had a maximum ground amplitude at $\mathrm{Kew}$ of $72 \mu$, and finished recording at $09 \mathrm{~h} .40 \mathrm{~m}$. U.T. The third disturbance, on March 5, began recording near $19 \mathrm{~h}$. $59 \mathrm{~m}$. 56s. U.T., though the start of $i P$ was somewhat confused by microseisms. The epicentral distance may have been near $8,200 \mathrm{~km}$., the long waves were of small amplitude, and the shock finished recording at $21 \mathrm{~h} .10 \mathrm{~m}$. U.T.

\section{Announcements}

ON the joint recommendation of the presidents of the Royal Society and the Institution of Civil Engineers, the James Alfred Ewing Medal for 1941 has been awarded to Dr. F. W. Lanchester. The Medal is awarded annually for specially meritorious contributions to the science of engineering in the field of research.

THE first Sir Joseph J. Thomson Memorial Lecture of the Chemical Society will be given by Lord Rayleigh, in the Lecture Theatre of the Royal Institution on April 16 at 4.30 p.m.

Prof. B. K. Malinowskr, University professor of anthropology in the London School of Economics who now holds the position of Bishop Museum visiting professor of anthropology in Yale University, has been appointed professor of cultural anthropology at that University as from July 1.

Prof. Emir Abderhalden, professor of physiology at Halle and for many years president of the German Academy of Natural Sciences at Halle, has had the latter appointment extended for another ten years.

Aт a meeting of the Quekett Microscopical Club, held on March 21, the following officers were elected : President, Mr. W. E. Watson Baker ; Hon. Librarian, Mr. C. Best; Hon. Curator, Mr. C. Sidwell; Hon. Secretary, Miss C. Arnold.

The following awards in respect of the year 1941 were made at the annual corporate meeting of the Institution of Chemical Engineers on March 27. The Osborne Reynolds Medal, for meritorious work accomplished for the advancement of the Institution during the year, to Dr. A. Parker, honorary editor and recorder of the Institution ; the Moulton Medal (in gold), for the best chemical engineering paper of the year, of a mature character, read before the Institution and published in the Transactions, to $\mathrm{Mr}$. P. Parrish, for his paper "Modern Developments in the Design of Plant for the Concentration of Sulphuric Acid"; the Junior Moulton Medal for 1941 was not awarded; the William Macnab Medal, for the best set of answers submitted in the associate-membership examination during the year, to Mr. E. W. Pates. 